\title{
SOIL FERTILITY, RATOON SUGARCANE YIELD, AND POST-HARVEST RESIDUES AS AFFECTED BY SURFACE APPLICATION OF LIME AND GYPSUM IN SOUTHEASTERN BRAZIL
}

\author{
FERTILIDADE DO SOLO, PRODUTIVIDADE DE CANA SOCA E RESIDUOS PÓS- \\ COLHEITA AFETADOS PELA APLICAÇÃO SUPERFICIAL DE CALCÁRIO E \\ GESSO NA REGIÃO SUDESTE DO BRASIL
}

\author{
Otavio Bagiotto ROSSATO ${ }^{1}$; Rodrigo FOLTRAN ${ }^{2}$; Carlos Alexandre Costa CRUSCIOL ${ }^{3}$; \\ Jorge Martinelli MARTELLO ${ }^{2}$; Raffaella ROSSETTO ${ }^{4}$; James Mabry McCRAY ${ }^{5}$ \\ 1. Professor do Instituto Federal Catarinense - IFC, Concórdia, SC, Brazil. otavio.rossato@ifc-concordia.edu.br; 2. Doutorando da \\ Faculdade de Ciências Agronômicas, FCA - UNESP, Botucatu, SP, Brazil; 3. Professor da Faculdade de Ciências Agronômicas, FCA - \\ UNESP, Botucatu, SP, Brazil; 4. Pesquisadora da Agência Paulista de Tecnologia do Agronegócio - APTA, Piracicaba, SP, Brazil; 5. \\ Associate Scientist of Everglades Research and Education Center, University of Florida, Belle Glade, Florida, USA.
}

\begin{abstract}
The aim of this study was to evaluate soil fertility amendment, stalk yield, sugar, bagasse, and trash yield as affected by surface application of dolomitic limestone and gypsum in green sugarcane ratoon. A factorial arrangement of four dolomitic limestone rates $\left(0,900,1800\right.$, and $\left.3600 \mathrm{~kg} \mathrm{ha}^{-1}\right)$ and two gypsum rates $\left(0\right.$ and $\left.1700 \mathrm{~kg} \mathrm{ha}^{-1}\right)$ was used in the experiment. The experiment was performed from October 2006 to October 2007, starting in the rainy season after the $2^{\text {nd }}$ ratoon harvest of the variety SP813250 in a commercial green sugarcane plantation of the São Luiz Sugar Mill (47²5'33" W; 2159'46”, 627 m of altitude), located in Pirassununga, state of São Paulo, in southeast Brazil. After 12 months, the experiment was harvested, technological measurements of stalk yield were made, and soil samples were taken and analyzed. Gypsum acts as a subsurface conditioner thus contributing so the benefits of surface limestone application, on soil acidity correction, to reach deeper layers, allowing the development of the root system of plants in greater depth. However, application of gypsum may lead to leaching of $\mathrm{Mg}$ and $\mathrm{K}$ from the topsoil layers. The higher rates of lime in surface application provided acidity amendment and, consequently, increased soil fertility in the soil profile, and increased sugarcane stalk, sugar, bagasse, and trash yield.
\end{abstract}

KEYWORDS: Sacharum spp. Soil chemical properties. Stalks. Sugar. Bagasse and trash.

\section{INTRODUCTION}

Soil acidity limits agricultural production in a considerable part of the world. In Brazil, approximately $70 \%$ of the land is composed of acid soils, which may reduce crop production potential by around $40 \%$. Plants do not develop well in acid soils, above all because of $\mathrm{Al}$ toxicity and $\mathrm{Ca}$ deficiency (RAIJ, 2011).

To correct soil acidity, the materials used are commonly oxides, hydroxides, silicates, and carbonates. Limestone is the most widely used material (ALCARDE; RODELLA, 2003). Gypsum, the residue from production of triple superphosphate, and even mineral calcium sulfate, are used as soil conditioners since they have high solubility and mobility in the soil profile, without amending soil acidity. These two products lead to availability of the $\mathrm{Ca}^{2+}$ and $\mathrm{SO}_{4}{ }^{2-}$ ions in the soil solution, enriching the subsoil layers with nutrients and reducing $\mathrm{Al}^{3+}$ saturation at soil depths (ALCARDE; RODELLA, 2003).

Recommendations for soil acidity amendments in sugarcane were developed in a burned sugarcane harvest system. Currently, harvest of green sugarcane, without burning, is already a reality in $70 \%$ of the cane fields of São Paulo and has been growing significantly in most regions of Brazil. In sugarcane harvest without prior burning, a straw trash cover from 10 to $20 \mathrm{t} \mathrm{ha}^{-1}$ year $^{-1}$ of dry matter remains on the soil surface (VITTI et al., 2008). The application of soil acidity amendments in this system where the straw remains on the soil has been carried out with little scientific foundation.

Studies on soil amendment in areas under the no-tillage system for grain production have shown that the effect of liming applied on the surface for amendment of subsoil layers varies with the application rate and particle size of the product, the form of application, the type of soil, the climatic conditions (especially water regime), the growing system, and the period of time since application (CAIRES et al., 2005; ALLEONI et al., 2005; SORATTO; CRUSCIOL, 2008a; ROSSATO et al. 2009), which leads to controversy regarding the effectiveness of this practice, particularly for acidity amendment of the subsoil. 
It is known that soils after liming exhibit a fall in base saturation at the time of renovation of the sugarcane field and decreases in $\mathrm{Ca}, \mathrm{Mg}$, and $\mathrm{K}$ over the period of cuttings (MORELLI et al., 1992). Associated with the fall in soil fertility, there is a progressive decline in production, which, over the period of cuttings, will culminate in the need for renewal of the cane field, which is one of the most costly phases of the production system. Thus, it is necessary to verify if limestone and gypsum application over the cane straw can lead to soil acidity amendment in the subsoil, increasing the yield and longevity of the cane field.

In recent years, the burning of bagasse from sugarcane not only provides electric power for operation of the sugar mills, but the surplus electric power produced is sold to electric power distribution companies. Driven mainly by the increase in electric power prices in the free market, mills are gradually increasing their installed capacity and electric power production (UDOP, 2014). According to the National Report on Power Balance (BEN, 2014), the increase in electric power from sugarcane bagasse in 2013 was $19.2 \%$ compared to the previous year. Participation in the Brazilian energy matrix increased from $4.2 \%$ in 2012 to $4.9 \%$ in 2013. Moreover, bagasse and trash (post-harvest residues) are beginning to be used for production of ethanol from second generation or cellulosic ethanol. Therefore, with the introduction of this new source of income, parameters such as the sugarcane bagasse and trash should be considered together with the stalk and sugar yield in making decisions about which agricultural practices should be adopted.

Thus the aim of this study was to evaluate soil acidity amendment, and stalk, sugar, bagasse, and trash biomass yield as affected by different rates of surface application of dolomitic limestone and gypsum on green sugarcane ratoon.

\section{MATERIAL AND METHODS}

The experiment was performed from October 2006 to October 2007, starting in the rainy season after the $2^{\text {nd }}$ ratoon harvest of the variety SP813250 in a commercial green sugarcane

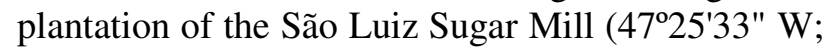
$21^{\circ} 59^{\prime} 46 ", 627 \mathrm{~m}$ of altitude), located in Pirassununga, state of São Paulo, in southeast Brazil. The climate is Aw (Tropical Savanna, by the Köppen classification) and the area is flat. Daily rainfall was registered during the experiment, and the results showed $102 \mathrm{~mm}$ in October, $120 \mathrm{~mm}$ in November, $175 \mathrm{~mm}$ in December, $275 \mathrm{~mm}$ in
January, $172 \mathrm{~mm}$ in February, $164 \mathrm{~mm}$ in March, 62 $\mathrm{mm}$ in April, $58 \mathrm{~mm}$ in May, $18 \mathrm{~mm}$ in June, $15 \mathrm{~mm}$ in July, $15 \mathrm{~mm}$ in August, $28 \mathrm{~mm}$ in September, and $84 \mathrm{~mm}$ in October, for a total of $1,288 \mathrm{~mm}$.

The soil is classified as kaolinitic, thermic Typic Haplorthox, with a sandy loam texture. Immediately after the harvest of the second ratoon and before initiating the experiment, soil chemical and textural characteristics were determined. Thus, ten subsamples were taken from the experimental area between the ratoon rows and combined into one composite sample with respective results for the topsoil $(0.00-0.20 \mathrm{~m})$ and subsoil $(0.20-0.40 \mathrm{~m})$ as follows: $\mathrm{pH}$ of 4.8 and 4.7, soil organic matter of 23.6 and $16.8 \mathrm{~g} \mathrm{dm}^{-3}, \mathrm{P}$ (resin) of 7.0 and $4.0 \mathrm{mg}$ $\mathrm{dm}^{-3}, \mathrm{Si}$ of 5.4 and 5.1 , and $\mathrm{S}$ of 6.0 and 4.0. Exchangeable $\mathrm{K}, \mathrm{Ca}, \mathrm{Mg}$, and $\mathrm{Al}$, $\mathrm{CEC}$ (cation exchange capacity), and $\mathrm{H}+\mathrm{Al}$ (total acidity $\mathrm{pH} 7.0$ ), for the topsoil $(0.00-0.20 \mathrm{~m})$ and subsoil $(0.20-0.40$ $\mathrm{m})$, were 1.7 and 1.0, 17 and $12.5,6.15$ and $4.9,1.3$ and 2.8, 53.9 and 49.0, 29.3 and $30.6 \mathrm{mmolc} \mathrm{dm}^{-3}$, respectively. Base saturation for the topsoil $(0.00-$ $0.20 \mathrm{~m})$ and subsoil $(0.20-0.40 \mathrm{~m})$ was 46.1 and $37.6 \%$, respectively. Sand, silt, and clay contents for the topsoil (0.00-0.20 m) and subsoil (0.20-0.40 m) were 693 and 677, 43 and 34, and 264 and $289 \mathrm{~g}$ $\mathrm{kg}^{-1}$, respectively.

Soil $\mathrm{pH}$ was determined in $0.01 \mathrm{~mol} \mathrm{~L}^{-1}$ $\mathrm{CaCl}_{2}$ (RAIJ et al., 2001), SOM (soil organic matter) by the colorimetric method (RAIJ et al. 2001), P from extraction by ion exchange resin and determination by colorimetry (RAIJ et al., 2001), S by $0.5 \mathrm{~mol} \mathrm{~L}^{-1} \mathrm{NH}_{4} \mathrm{OAc}$ in $0.25 \mathrm{~mol} \mathrm{~L}^{-1} \mathrm{HOAc}$ (VITTI, 1988), K from extraction by ion exchange resin and determination by flame photometry (RAIJ et al., 2001), $\mathrm{Ca}$ and $\mathrm{Mg}$ from extraction by ion exchange resin and determination by atomic absorption spectrometry (RAIJ et al., 2001), H+Al (total acidity at $\mathrm{pH}$ 7.0) from determination by a potentiometer in SMP-buffer solution (RAIJ et al., 2001), Al by $1 \mathrm{~mol} \mathrm{~L}^{-1} \mathrm{KCl}$ (RAIJ et al., 2001), and $\mathrm{Si}$ from extraction by $0.5 \mathrm{~mol} \mathrm{~L}^{-1}$ acetic acid and determination by a spectrophotometer at $660 \mathrm{~nm}$ (KORNDÖRFER et al., 1999).

A randomized block experimental design was used in a factorial arrangement, with four replications. Treatments consisted of four dolomitic limestone rates $\left(0 ; 900 ; 1,800\right.$; and 3,600 $\left.\mathrm{kg} \mathrm{ha}^{-1}\right)$ and two gypsum rates ( 0 and $\left.1,700 \mathrm{~kg} \mathrm{ha}^{-1}\right)$. Each plot consisted of eight sugarcane rows of $12 \mathrm{~m}$ length, spaced at $1.4 \mathrm{~m}$.

Dolomitic limestone composition was $40 \%$ $\mathrm{CaO}, 12.0 \% \mathrm{MgO}$, and $85 \%$ effective calcium carbonate equivalence (ECCE). The composition of gypsum $\left(\mathrm{CaSO}_{4} \cdot 2 \mathrm{H}_{2} \mathrm{O}\right)$, a by-product obtained from 
a Brazilian phosphoric acid industry, was $20 \% \mathrm{Ca}$, $16 \% \mathrm{~S}$, and a small residue of $0.1 \% \mathrm{P}$ and $\mathrm{F}$.

The dolomitic limestone rate (LR) was calculated so as to increase the base saturation in soil $(0.00-0.40 \mathrm{~m})$ to $60 \%$ according to Spironello et al. (1996). For this purpose, the soil chemical characteristics determined in topsoil $(0.00-0.20 \mathrm{~m})$ were used, and the result obtained from the amount of dolomitic limestone is multiplied by two (SPIRONELLO et al., 1996) as follows in equation 1 :

$\operatorname{LR}\left(\mathrm{kg} \mathrm{ha}^{-1}\right)=\left\{\left[\left(\mathrm{BS}_{2}-\mathrm{BS}_{1}\right) * \mathrm{CEC}\right] /\left(\mathrm{ECCE}^{*} 10\right)\right\} * 2[1]$

$\mathrm{BS}_{2}$ is the estimated base saturation (60\%)

and $\mathrm{BS}_{1}$ is the base saturation measured in soil analysis, as in equation 2 :

$\mathrm{BS}(\%)=[(\mathrm{Caex}+\mathrm{Mgex}+\mathrm{Kex}) / \mathrm{CEC}] * 100$

Caex, Mgex, and Kex are basic exchangeable cations and CEC is the total cation exchange capacity, calculated according to equation 3:

CEC $\left(\right.$ mmolc dm $\left.{ }^{-3}\right)=\mathrm{Ca}_{\mathrm{ex}}+\mathrm{Mg}_{\mathrm{ex}}+\mathrm{K}_{\mathrm{ex}}+$ total acidity at pH $7.0(\mathrm{H}+\mathrm{Al})$

The lime rates were defined as the control $(0$ $\left.\mathrm{kg} \mathrm{ha}^{-1}\right)$, half the rate recommended $\left(900 \mathrm{~kg} \mathrm{ha}^{-1}\right)$, the rate recommended $\left(1,800 \mathrm{~kg} \mathrm{ha}^{-1}\right)$, and double the rate recommended $\left(3,600 \mathrm{~kg} \mathrm{ha}^{-1}\right)$. Before application of the products, lime and gypsum were mixed, according to the treatments, and they were packed in plastic bags.

The gypsum rate (GR) was calculated through equation 4 :

$\mathrm{GR}\left(\mathrm{kg} \mathrm{ha}^{-1}\right)=6 \mathrm{CL}$

$\mathrm{CL}$ is the clay content $\left(\mathrm{g} \mathrm{kg}^{-1}\right)$ in the 0.20 $0.40 \mathrm{~m}$ soil layer.

Thus, products were applied over the sugarcane harvest residue layer (12.2 ton ha $\left.{ }^{-1}\right)$ and without soil incorporation, according to the treatments. Topdressing fertilization on the sugarcane ratoon was performed with $70 \mathrm{~kg} \mathrm{ha}^{-1}$ of $\mathrm{N}$ as ammonium nitrate and $80 \mathrm{~kg} \mathrm{ha}^{-1}$ of $\mathrm{K}_{2} \mathrm{O}$ as potassium chloride.

After 12 months, the experiment was harvested and soil samples were taken at the depths of $0.00-0.05,0.05-0.10,0.10-0.20,0.20-0.40$, and $0.40-0.60 \mathrm{~m}$ in all plots. Seven subsamples were taken at random from each plot between the rows and combined into one composite sample. Soil samples were chemically analyzed for $\mathrm{pH}$, SOM, $\mathrm{H}+\mathrm{Al}$, and $\mathrm{P}$, exchangeable $\mathrm{Al}, \mathrm{Ca}, \mathrm{Mg}$, and $\mathrm{K}$ (RAIJ et al., 2001) and S (VITTI, 1988). Using the results of exchangeable bases and total acidity at $\mathrm{pH}$ $7.0(\mathrm{H}+\mathrm{Al})$, base saturation values were calculated (RAIJ et al., 2001).

Stalk yield at harvest was determined in the four central rows, with two rows of plants being used for technological measurements (sugar concentration, purity, fiber, and reducing sugar). One meter was established at random in both plant rows; the stalks were collected, topped at apical bud height, defoliated, and then sent to the sugarcane technology laboratory, São Luiz Sugar Mill, to be processed according to the methodology defined in the Sucrose Content-Based Sugarcane Payment System, in accordance with Consecana's semiannual updates for the technological evaluations described in Fernandes (2011), considering the sugarcane total reducing sugars parameter. Using the results of stalk yield and sugar concentration, the sugar yield values were calculated, and using the results of fiber and stalk yield, bagasse values were calculated with $50 \%$ moisture. The quantity of trash (post-harvest residues) was calculated considering that $1 \mathrm{Mg}$ of stalk produces $140 \mathrm{~kg}$ of trash (HASSUANI et al., 2005) and that $50 \%$ of post-harvest residues were collected from the soil surface.

Data were subjected to ANOVA using SAS (SAS Institute, 1997). Gypsum application means were compared by Fisher's protected LSD test at the 0.05 probability level $(\mathrm{p}<0.05)$. Dolomitic limestone rates were analyzed through regression analysis, adopting the magnitude of the regression coefficients that were significant at the 0.05 probability level $(\mathrm{p}<0.05)$ by the $\mathrm{t}$ test as the criterion for choosing the model.

\section{RESULTS AND DISCUSSION}

The limestone application rates increased the $\mathrm{pH}$ in $\mathrm{CaCl}_{2}$ of the soil in a linear manner and reduced exchangeable $\mathrm{Al}$ and saturation by $\mathrm{Al}$ up to the $0.40-0.60 \mathrm{~m}$ layer and potential acidity $(\mathrm{H}+\mathrm{Al})$ up to the $0.20-0.40 \mathrm{~m}$ layer (Table 1). This greater concentration of ions resulting from the neutralization reaction at the higher limestone application rates allows the negative charges of the soil arising from the increase of $\mathrm{pH}$ to be filled, making the excess of cations available to the soil solution in a shorter period of time, which makes displacement of the alkaline front possible in the subsoil, confirming the affirmation of Caires et al. (2004) for the application of acidity amendments on the soil surface.

Physical movement of the limestone by root channels, biological microchannels (biopores) and planes/zones of weakness in the soil itself (AMARAL et al., 2004), has been indicated as the main factor that contributes to acidity amendment at soil depths. In addition, high amounts of rainfall in the months following limestone application may have contributed to amendment of the soil profile. 
Table 1. Values of $\mathrm{pH}, \mathrm{H}+\mathrm{Al}$ (total acidity $\mathrm{pH}$ 7.0), exchangeable $\mathrm{Al}^{3+}\left(\mathrm{Al}_{\mathrm{ex}}\right)$, and $\mathrm{m} \%\left(\mathrm{Al}^{3+}\right.$ saturation) of soil samples taken 12 months after dolomitic lime and gypsum surface application in green sugarcane and ANOVA significance at five soil depths in Pirassununga, São Paulo, Brazil.

\begin{tabular}{|c|c|c|c|c|c|c|c|c|}
\hline \multirow{2}{*}{$\begin{array}{l}\text { Characteristic } \\
\text { Gypsum, kg ha }\end{array}$} & \multicolumn{2}{|c|}{$\mathrm{pH}$} & \multicolumn{2}{|c|}{$\mathrm{H}+\mathrm{AL}$} & \multicolumn{2}{|c|}{$\mathrm{Al}_{\mathrm{ex}}$} & \multicolumn{2}{|c|}{$\mathrm{m} \%$} \\
\hline & $0^{(\mathrm{a})}$ & 1,700 & 0 & 1,700 & 0 & 1,700 & 0 & 1,700 \\
\hline
\end{tabular}

Lime, $\mathrm{kg} \mathrm{ha}^{-1}$

0

900

1,800

3,600

Mean

Effect

ANOVA

Lime $(\mathrm{L})$

Gypsum (P)

$\mathrm{L} * \mathrm{P}$

Lime, $\mathrm{kg} \mathrm{ha}^{-1}$

\begin{tabular}{lcc}
0 & 4.8 & 5.0 \\
900 & 5.0 & 5.1 \\
1,800 & 5.1 & 5.2 \\
3,600 & 5.4 & 5.6 \\
Mean & $5.1 \mathrm{a}$ & $5.2 \mathrm{a}$ \\
Effect & \multicolumn{2}{c}{$\mathrm{L}^{* *}$}
\end{tabular}

ANOVA

Lime (L)

Gypsum (P)

$\mathrm{L} * \mathrm{P}$

Lime, $\mathrm{kg} \mathrm{ha}^{-1}$

0

900

1,800

3,600

Mean

Effect

ANOVA

Lime (L)

Gypsum (P)

L*P

Lime, $\mathrm{kg} \mathrm{ha}^{-1}$

0
900
1,800
3,600
Mean
Effect
ANOVA
Lime (L)
Gypsum (P)
L*P

\begin{tabular}{cc}
4.9 & 5.1 \\
5.3 & 5.4 \\
5.4 & 5.4 \\
5.9 & 6.1 \\
$5.4 \mathrm{a}^{(\mathrm{b})}$ & $5.4 \mathrm{a}$ \\
\multicolumn{2}{c}{$\mathrm{L}^{(\mathrm{c})} * *$}
\end{tabular}

$<0.0001$

0.1254

0.1552

$<0.0001$

0.1291

0.1468

$\begin{array}{crr}4.9 & & 5.0 \\ 5.0 & & 5.0 \\ 5.0 & & 5.1 \\ 5.2 & & 5.4 \\ 5.0 \mathrm{a} & & 5.1 \mathrm{a} \\ & \mathrm{L}^{*} & \end{array}$

0.0249

0.1476

0.1504

$\begin{array}{crc}4.6 & & 4.8 \\ 4.8 & & 4.8 \\ 4.8 & & 4.8 \\ 4.9 & & 4.9 \\ 4.8 \mathrm{a} & & 4.8 \mathrm{a} \\ & \mathrm{L}^{*} & \end{array}$

0.0444

0.2529

0.2873

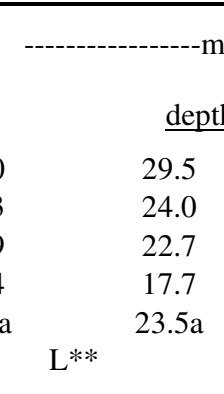

$<0.0001$

0.1152

0.1584

$\begin{array}{cc}\text { dept } \\ 28.3 \\ 25.4 \\ 24.8 \\ 17.3 \\ & 23.9 \mathrm{a} \\ \text { L** } & \end{array}$

$<0.0001$

0.1007

0.1437

27.3

26.5

26.0

24.5

26.1a

$$
\mathrm{L}^{* *}
$$

$<0.0001$

0.1099

0.1369

depth: $0.10-0.20 \mathrm{~m}$

$\begin{array}{ll}26.7 & 1.7 \\ 26.1 & 1.4\end{array}$

25.4

23.2

$25.4 \mathrm{a}$

1.3

1.3

$1.4 \mathrm{a}$

$$
\mathrm{L}^{*}
$$

0.0237

$<0.0001$

0.1358

$\%$ 
Lime, $\mathrm{kg} \mathrm{ha}^{-1}$

\begin{tabular}{lcc}
0 & 4.2 & 4.4 \\
900 & 4.4 & 4.5 \\
1,800 & 4.4 & 4.5 \\
3,600 & 4.5 & 4.7 \\
Mean & $4.4 \mathrm{a}$ & $4.5 \mathrm{a}$ \\
Effect & \multicolumn{2}{c}{ L* $^{*}$}
\end{tabular}

ANOVA

Lime (L)

Gypsum (P)

$\mathrm{L} * \mathrm{P}$
0.0487

0.2116

0.2331

depth: $0.40-0.60 \mathrm{~m}$

$\begin{array}{crr}36.6 & & 33.3 \\ 31.9 & & 29.8 \\ 34.0 & & 30.2 \\ 31.2 & & 30.8 \\ 33.4 \mathrm{a} & & 31.0 \mathrm{a}\end{array}$

0.0827

0.0722

0.1171

4.5

4.1

4.0

3.7

$4.1 \mathrm{a}$

$\mathrm{L}^{* *}$

$<0.0001$

$<0.0001$

0.1305

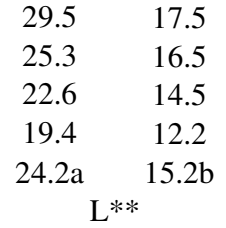

$<0.0001$

$<0.0001$

0.1091

* Significant at the 0.05 probability level, ${ }^{* *}$ significant at the 0.01 probability level and ${ }^{\text {ns }}$ represents no effect. ${ }^{(a)}$ Gypsum treatments $(0$ and $\left.1,700 \mathrm{~kg} \mathrm{ha}^{-1}\right) .{ }^{\text {(b) }}$ Values followed by the same letter in the rows, within each variable, are not significantly different at $P \leq 0.05$ according to the LSD test. ${ }^{(c)} \mathrm{L}$ represents linear effect by polynomial regression.

No effect was observed from application of gypsum on $\mathrm{pH}$ and $\mathrm{H}+\mathrm{Al}$. However, application of gypsum reduced the exchangeable $\mathrm{Al}$ contents and saturation by $\mathrm{Al}$ for all the layers. Some hypotheses, described by Raij (2008), have been suggested to explain the mechanism involved. One of them would be the release of $\mathrm{OH}^{-}$by $\mathrm{SO}_{4}{ }^{2-}$ through ligand exchange, with the formation of hydroxylated structures of aluminum, a mechanism called the "self-liming effect". Aluminum precipitation, with the formation of minerals, has also been indicated. Another possibility would be the leaching of aluminum accompanying the gypsum, which may in part be favored by the formation of ionic pairs or compounds such as $\mathrm{AlSO}_{4}^{+}$, or of aluminum fluoride.

Limestone application increased the $\mathrm{Ca}$ and $\mathrm{Mg}$ contents and base saturation in a linear and positive manner in all the soil layers evaluated, regardless of the application of gypsum (Table 2). These results corroborate those found by Soratto and Crusciol (2008a), who verified an increase in the $\mathrm{Ca}$ and $\mathrm{Mg}$ contents up to $0.60 \mathrm{~m}$ in an Oxisol 12 months after surface application of limestone in establishment of a no-tillage system (NTS). Displacement of the Ca-ligand and the Mg-ligand to subsoil layers occurs when the stability constant of the complex is greater than the stability constant of the calcium-soil and of the magnesium-soil (AMARAL et al., 2004). The displacement of $\mathrm{Ca}^{2+}$ and $\mathrm{Mg}^{2+}$ in the soil profile by limestone may be attributed to their high concentration, especially for $\mathrm{Ca}^{2+}$ in the surface layers, since it is well above the range considered as adequate, 4.0 to $7.0 \mathrm{mmol}_{\mathrm{c}} \mathrm{dm}^{-3}$ (RAIJ et al., 1996). Limestone was effective in raising base saturation to levels recommended for sugarcane $(60 \%)$ in the $0.0-0.05 \mathrm{~m}$ and $0.05-0.10 \mathrm{~m}$ layers for the lower rate $\left(900 \mathrm{~kg} \mathrm{ha}^{-1}\right)$ and rate recommended by Spironello et al. (1996) (1800 kg $\left.\mathrm{ha}^{-1}\right)$. For the highest rate $\left(3600 \mathrm{~kg} \mathrm{ha}^{-1}\right)$, this effect was observed up to the $0.05-0.10 \mathrm{~m}$ layer. This shows that the limestone application rate has a direct effect on the depth where the effect of the soil amendment is present. In addition, the results indicate that application rates higher than those recommended by Spironello et al. (1996) were more effective in amendment of the 0.0-0.10 m layer after 12 months.

Table 2. Values of exchangeable $\mathrm{Ca}, \mathrm{Mg}$, and $\mathrm{K}$, and base saturation of soil samples taken 12 months after dolomitic lime and gypsum surface application in green sugarcane, and ANOVA significance at five soil depths in Pirassununga, São Paulo, Brazil.

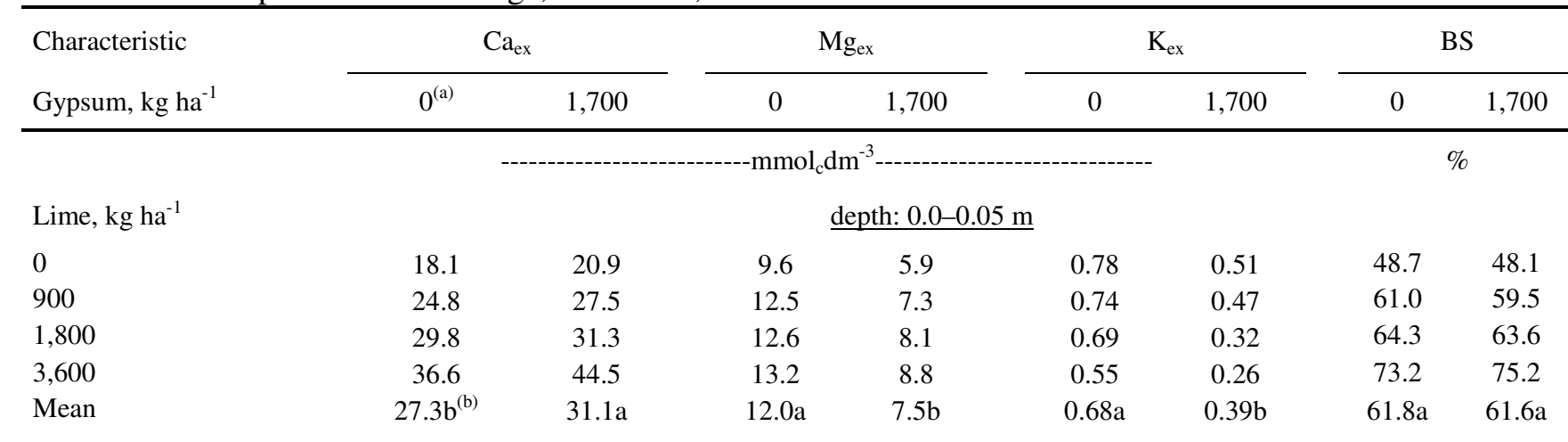


Soil fertility, ratoon sugarcane yield...

$\begin{array}{lc}\text { Effect } & \mathrm{L}^{(\mathrm{c})} * * \\ \text { ANOVA } & \\ \text { Lime (L) } & <0.0001 \\ \text { Gypsum (P) } & <0.0001 \\ \text { L*P } & 0.1269\end{array}$

Lime, $\mathrm{kg} \mathrm{ha}^{-1}$

0

900

1,800

3,600

Mean

Effect

ANOVA

Lime (L)

Gypsum (P)

L*P

$\begin{array}{crr}16.2 & & 18.2 \\ 19.2 & & 19.3 \\ 19.7 & & 23.3 \\ 26.7 & & 35.9 \\ 20.4 b & & 24.2 \mathrm{a}\end{array}$

$<0.0001$

$<0.0001$

0.1415

Lime, $\mathrm{kg} \mathrm{ha}^{-1}$

0

900

1,800

3,600

Mean

Effect

ANOVA

Lime (L)

Gypsum (P)

$\mathrm{L} * \mathrm{P}$

$\begin{array}{crc}17.2 & 17.9 \\ 18.1 & 18.8 \\ 18.8 & 20.1 \\ 20.2 & 20.8 \\ 18.6 \mathrm{a} & 19.4 \mathrm{a} \\ & \text { L** }\end{array}$

$<0.0001$

0.1207

0.1399

Lime, $\mathrm{kg} \mathrm{ha}^{-1}$

0

900

1,800

3,600

Mean

Effect

ANOVA

Lime (L)

Gypsum (P)

L*P

Lime, $\mathrm{kg} \mathrm{ha}^{-1}$

\begin{tabular}{lcr}
0 & 7.3 & 11.6 \\
900 & 8.2 & 12.0 \\
1,800 & 9.6 & 12.8 \\
3,600 & 11.2 & 13.0 \\
Mean & $9.1 \mathrm{~b}$ & $12.3 \mathrm{a}$ \\
Effect & \multicolumn{2}{c}{$\mathrm{L}^{* *}$} \\
ANOVA & \multicolumn{2}{c}{} \\
Lime (L) & \multicolumn{2}{c}{$<0.0001$} \\
Gypsum (P) & \multicolumn{2}{c}{$<0.0001$} \\
L*P & \multicolumn{2}{c}{0.0953} \\
\hline
\end{tabular}

$<0.0001$
ROSSATO, O. B. et al.

$\begin{array}{cc}\mathrm{L} * * & \mathrm{~L} * * \\ <0.0001 & <0.0001 \\ <0.0001 & 0.1659 \\ 0.1553 & 0.2084\end{array}$

depth: $0.05-0.10 \mathrm{~m}$

\begin{tabular}{cccccc}
6.7 & 5.2 & 0.74 & 0.37 & 44.2 & 45.7 \\
8.3 & 6.7 & 0.69 & 0.37 & 51.6 & 50.9 \\
9.8 & 7.3 & 0.47 & 0.31 & 54.2 & 55.5 \\
9.9 & 7.4 & 0.41 & 0.28 & 61.9 & 71.6 \\
$8.7 \mathrm{a}$ & $6.7 \mathrm{~b}$ & $0.58 \mathrm{a}$ & $0.33 \mathrm{~b}$ & $53.0 \mathrm{a}$ & $55.9 \mathrm{a}$ \\
\multicolumn{2}{c}{$\mathrm{L}^{* *}$} & \multicolumn{2}{c}{$\mathrm{L}^{* *}$} & \multicolumn{2}{c}{$\mathrm{L}^{* *}$}
\end{tabular}

$$
\begin{array}{ccc}
<0.0001 & <0.0001 & <0.0001 \\
<0.0001 & <0.0001 & 0.1271 \\
0.1257 & 0.1308 & 0.1533
\end{array}
$$

depth: $0.10-0.20 \mathrm{~m}$

\begin{tabular}{cccccc}
5.3 & 6.0 & 0.35 & 0.20 & 45.6 & 47.4 \\
6.2 & 6.4 & 0.24 & 0.18 & 48.1 & 49.3 \\
6.8 & 6.8 & 0.22 & 0.15 & 49.8 & 51.6 \\
7.5 & 7.7 & 0.22 & 0.12 & 53.3 & 55.2 \\
$6.4 \mathrm{a}$ & $6.7 \mathrm{a}$ & $0.26 \mathrm{a}$ & $0.16 \mathrm{~b}$ & $49.2 \mathrm{a}$ & $50.9 \mathrm{a}$ \\
\multicolumn{2}{c}{$\mathrm{L}^{* *}$} & \multicolumn{2}{c}{$\mathrm{L}^{* *}$} & \multicolumn{2}{c}{$\mathrm{L}^{* *}$}
\end{tabular}

$\begin{array}{ccc}<0.0001 & <0.0001 & <0.0001 \\ 0.1211 & <0.0001 & 0.1246 \\ 0.1291 & 0.1337 & 0.1414\end{array}$

depth: $0.20-0.40 \mathrm{~m}$

\begin{tabular}{cccccccc}
12.2 & 12.5 & 5.0 & 5.8 & 0.19 & 0.11 & 36.5 & 37.9 \\
14.0 & 14.2 & 5.4 & 5.8 & 0.15 & 0.11 & 40.3 & 40.9 \\
15.2 & 15.9 & 5.6 & 6.1 & 0.15 & 0.07 & 42.3 & 43.6 \\
15.9 & 16.0 & 5.6 & 7.0 & 0.13 & 0.08 & 43.4 & 46.4 \\
$14.3 \mathrm{a}$ & $14.7 \mathrm{a}$ & $5.4 \mathrm{~b}$ & $6.2 \mathrm{a}$ & $0.16 \mathrm{a}$ & $0.09 \mathrm{~b}$ & $40.6 \mathrm{a}$ & $42.2 \mathrm{a}$ \\
& & \multicolumn{2}{c}{$\mathrm{L}^{*}$} & & \multicolumn{2}{c}{$\mathrm{L}^{*}$} & \multicolumn{2}{c}{$\mathrm{L}^{*}$} & \multicolumn{2}{c}{$\mathrm{L}^{*}$}
\end{tabular}

$<0.0001$

$<0.0001$

$<0.0001$

$<0.0001$

$<0.0001<0.0001$

0.1106

0.1207

0.1002

depth: $0.40-0.60 \mathrm{~m}$

\begin{tabular}{cccccc}
3.3 & 4.3 & 0.13 & 0.64 & 22.7 & 33.2 \\
3.8 & 4.4 & 0.10 & 0.32 & 27.5 & 35.9 \\
4.0 & 4.7 & 0.10 & 0.18 & 28.7 & 36.9 \\
4.1 & 4.9 & 0.10 & 0.13 & 33.0 & 36.9 \\
$3.8 \mathrm{~b}$ & $4.6 \mathrm{a}$ & $0.1 \mathrm{~b}$ & $0.3 \mathrm{a}$ & $28.0 \mathrm{a}$ & $35.7 \mathrm{~b}$ \\
\multicolumn{2}{l}{$\mathrm{L}^{*}$} & & \multicolumn{4}{c}{$\mathrm{L}^{*}$} & \multicolumn{4}{c}{$\mathrm{L}^{*}$}
\end{tabular}

$<0.0001 \quad<0.0001 \quad 0.0315$

$<0.0001<0.0001 \quad 0.0402$

$0.0845 \quad 0.1085 \quad 0.0859$

* Significant at the 0.05 probability level. ** Significant at the 0.01 probability level. ${ }^{\text {(a) }}$ Gypsum treatments $\left(0\right.$ and $1,700 \mathrm{~kg}$ ha $\left.{ }^{-1}\right) .{ }^{(b)}$ Values followed by the same letter in the rows, within each variable, are not significantly different at $P \leq 0.05$ according to the LSD test.

${ }^{\text {(c) }} \mathrm{L}$ represents linear effect by polynomial regression. 
The binding energy of the $\mathrm{Ca}, \mathrm{Mg}$ and $\mathrm{K}$ exchangeable cations to the soil colloids depends on the valence and the size of the hydrated ion, such that in well-drained soils, the quantities of leached $\mathrm{K}$ are relatively greater than those of the bivalent cations. For K, it may be observed that the application of increasing rates of limestone reduced the contents of this nutrient throughout the profile, regardless of the use of gypsum. These results may have occurred because, with the addition of limestone in a soil where the levels of $\mathrm{Ca}$ and $\mathrm{Mg}$ were already at a level considered to be high (RAIJ et al. 1996), there was displacement of $\mathrm{K}$ beyond the $0.6 \mathrm{~m}$ depth evaluated. In addition, it is possible that the plants found better growing conditions at the greater limestone application rates and, therefore, took up greater amounts of $\mathrm{K}$.

Gypsum led to an increase in the $\mathrm{Ca}$ contents throughout the soil profile. In addition to movement of $\mathrm{Ca}$, gypsum also led to displacement of exchangeable $\mathrm{Mg}$ up to the depth of $0.10 \mathrm{~m}$, shown by the lower $\mathrm{Mg}$ contents found when gypsum was applied. Gypsum provided for a gradual increase in $\mathrm{Mg}$ up to the depth of 0.40-0.60 $\mathrm{m}$, corroborating the data found by Caires et al. (2006) in wheat. Thus, although the leaching of $\mathrm{Mg}$ to deeper soil layers is considered to be a negative effect of the use of gypsum, this effect was not so serious for sugarcane since the sugarcane root system is deep and extensive.

For phosphorus (Table 3), there was also a linear increase in the soil contents with increasing rates of limestone application. The use of limestone assisted desorption of $\mathrm{P}$ because, with the rise in $\mathrm{pH}$, there was an increase in the solubility of the iron and aluminum phosphates and an increase in the $\mathrm{OH}^{-}$concentration in the soil solution, reducing the adsorption of phosphate in the solid phase of the soil (CASAGRANDE et al., 2003; CAMARGO et al., 2010).

Table 3. Values of $P$, sulfate and organic matter of soil samples taken 12 months after dolomitic lime and gypsum surface application in green sugarcane, and ANOVA significance at five soil depths in Pirassununga, São Paulo, Brazil.

\begin{tabular}{|c|c|c|c|c|c|c|}
\hline \multirow{2}{*}{$\begin{array}{l}\text { Characteristic } \\
\text { Gypsum, kg ha }\end{array}$} & \multicolumn{2}{|c|}{$\mathrm{P}$} & \multicolumn{2}{|c|}{$\mathrm{S}-\mathrm{SO}_{4}{ }^{-2}$} & \multicolumn{2}{|c|}{ SOM } \\
\hline & $0^{(\mathrm{a})}$ & 1,700 & 0 & 1,700 & 0 & 1,700 \\
\hline & \multicolumn{4}{|c|}{ 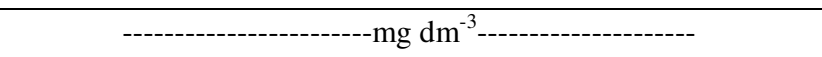 } & \multicolumn{2}{|c|}{$\mathrm{g} \mathrm{dm}^{-3}$} \\
\hline Lime, $\mathrm{kg} \mathrm{ha}^{-1}$ & \multicolumn{6}{|c|}{ depth: $0.0-0.05 \mathrm{~m}$} \\
\hline 0 & 3.6 & 5.9 & 5.7 & 8.3 & 28.2 & 28.7 \\
\hline 900 & 6.8 & 7.6 & 5.9 & 10.0 & 26.5 & 26.4 \\
\hline 1,800 & 9.3 & 10.1 & 7.2 & 11.9 & 27.1 & 27.9 \\
\hline 3,600 & 14.1 & 16.2 & 9.4 & 15.0 & 26.8 & 27.4 \\
\hline Mean & $8.4 b^{(b)}$ & $9.9 \mathrm{a}$ & $7.0 \mathrm{~b}$ & $11.3 \mathrm{a}$ & $27.1 \mathrm{a}$ & $27.6 \mathrm{a}$ \\
\hline
\end{tabular}

The application of limestone led to a linear increase in the $\mathrm{SO}_{4}^{-2}$ contents throughout the soil layers. With application of limestone, there is a rise in $\mathrm{pH}$ (Table 1), which promotes the increase in $\mathrm{SO}_{4}^{-2}$ availability both by reducing its adsorption (CASAGRANDE et al., 2003) and by increasing release of the adsorbed amount. In addition, there was also greater mineralization of the soil organic matter with a rise in soil $\mathrm{pH}$ (ALVAREZ et al., 2007).

The application of gypsum significantly increased the $\mathrm{P}$ contents in the soil throughout the profile. In spite of the small quantity of $\mathrm{P}$ present in the gypsum (1\%), it was able to increase the $\mathrm{P}$ contents by around $1 \mathrm{mg} \mathrm{dm}^{-3}$. Other authors such as Caires et al. (2011) and Silva et al. (2010) also observed an increase in phosphorus contents through the application of gypsum.

Gypsum led to an increase in the $\mathrm{SO}_{4}^{-2}$ contents in all the soil layers; however, it was observed that in the deepest layers, $0.20-0.40$ and $0.40-0.60 \mathrm{~m}$, the greatest contents of $\mathrm{SO}_{4}{ }^{-2}$ were found, indicating descent of this nutrient in the soil profile. The small retention of $\mathrm{S}_{-} \mathrm{SO}_{4}{ }^{-2}$ in the soil surface layers may be attributed to the greater $\mathrm{pH}$ values observed in these layers. The higher $\mathrm{pH}$ promotes the predominance of negative electrical charges, which favor the movement of $\mathrm{S}_{-} \mathrm{SO}_{4}^{-2}$ (SORATTO; CRUSCIOL, 2008b).

Organic matter was not affected either by the application of limestone or by the application of gypsum in the layers evaluated. The acidity amendments, through increasing $\mathrm{pH}$, may accelerate mineralization of organic matter and may reduce its content in the soil in a short time. In this study, however, there was no change in the organic matter content in the soil profile through surface application of limestone and gypsum, corroborating the data of Zambrosi et al. (2007) in an area under the no-tillage system with surface application of limestone and gypsum. 


\begin{tabular}{lccr}
\hline Effect & $\mathrm{L}^{(\mathrm{c}) * *}$ & $\mathrm{~L}^{*}$ & ns \\
ANOVA & & & 0.0481 \\
Lime (L) & $<0.0001$ & $<0.0001$ & 0.2857 \\
Gypsum (P) & 0.0422 & 0.1934 & 0.2694 \\
L*P & 0.1328 & & 0.2677
\end{tabular}

Lime, $\mathrm{kg} \mathrm{ha}^{-1}$

0

900

1,800

3,600

Mean

Effect

ANOVA

Lime (L)

Gypsum (P)

L*P

Lime, $\mathrm{kg} \mathrm{ha}^{-1}$

0

900

1,800

3,600

Mean

Effect

ANOVA

Lime (L)

Gypsum (P)

$\mathrm{L} * \mathrm{P}$

2.4

$$
\text { L* }
$$

$<0.0001$

0.0227

0.1404

4.0

5.0

5.9

7.0

$5.4 \mathrm{a}$

2.4

3.1

4.6

5.1

$3.8 \mathrm{~b}$

Lime, $\mathrm{kg} \mathrm{ha}^{-1}$

0

900

1,800

3,600

Mean

Effect

ANOVA

Lime (L)

Gypsum (P)

L*P

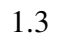

1.9

2.0

2.3

$1.9 \mathrm{~b}$

Lime, $\mathrm{kg} \mathrm{ha}^{-1}$

0

900

1,800

3,600

Mean

Effect

ANOVA

Lime (L)

Gypsum (P)

$\mathrm{L} * \mathrm{P}$

$1.0 \quad 2.1$

$1.3 \quad 2.6$

$\begin{array}{ll}1.7 & 2.7\end{array}$

$\begin{array}{ll}1.9 & 3.7\end{array}$

$1.5 \mathrm{~b}$

$\mathrm{L}^{*}$

$2.8 \mathrm{a}$

$<0.0001$

0.0407

0.1531

3.2

3.3

3.3

3.4

$3.3 \mathrm{a}$

Significant at the 0.05 probability level, $* *$ significant at the 0.01 probability level, and ${ }^{\text {ns }}$ represents no e

effect. ${ }^{(a)}$ Gypsum treatments ( 0 and $1,700 \mathrm{~kg}$ ha represents linear effect by polynomial regression.

\begin{tabular}{|c|c|c|c|}
\hline 4.4 & 7.3 & 24.5 & 25.7 \\
\hline 4.7 & 8.0 & 23.5 & 24.0 \\
\hline 5.2 & 9.2 & 25.0 & 25.2 \\
\hline 5.4 & 38.3 & 25.4 & 23.8 \\
\hline $4.9 \mathrm{~b}$ & $15.7 \mathrm{a}$ & $26.8 \mathrm{a}$ & $27.4 \mathrm{a}$ \\
\hline
\end{tabular}

depth: $0.05-0.10 \mathrm{~m}$

0.1927

0.1815

0.2098

\begin{tabular}{|c|c|c|c|}
\hline 4.1 & 10.0 & 19.4 & 21.8 \\
\hline 4.2 & 10.9 & 22.7 & 22.7 \\
\hline 5.3 & 12.1 & 22.6 & 23.1 \\
\hline 6.4 & 40.7 & 22.6 & 23.4 \\
\hline $5.0 \mathrm{~b}$ & $18.4 \mathrm{a}$ & $21.8 \mathrm{a}$ & $22.8 \mathrm{a}$ \\
\hline
\end{tabular}

depth: $0.10-0.20 \mathrm{~m}$

0.0462

0.2011

0.2222

0.2351

\begin{tabular}{|c|c|c|c|}
\hline 6.2 & 27.4 & 21.2 & 22.5 \\
\hline 6.5 & 29.4 & 22.0 & 21.8 \\
\hline 7.5 & 39.7 & 23.1 & 22.9 \\
\hline 8.6 & 46.6 & 21.7 & 21.8 \\
\hline $2 b$ & $35.8 \mathrm{a}$ & $22.0 \mathrm{a}$ & $22.2 \mathrm{a}$ \\
\hline
\end{tabular}

depth: $0.20-0.40 \mathrm{~m}$

\begin{tabular}{|c|c|c|c|}
\hline 12.9 & 40.8 & 20.7 & 21.6 \\
\hline 14.3 & 45.4 & 21.0 & 23.0 \\
\hline 23.2 & 49.7 & 19.8 & 22.0 \\
\hline 26.3 & 52.2 & 20.6 & 21.1 \\
\hline $.2 b$ & $47.1 \mathrm{a}$ & $20.5 \mathrm{a}$ & $21.9 \mathrm{a}$ \\
\hline
\end{tabular}

depth: $0.40-0.60 \mathrm{~m}$

$\begin{array}{ll}0.0325 & 0.1869 \\ <0.0001 & 0.1992 \\ 0.1787 & 0.2025\end{array}$

0.2124

0.2099

0.2188

1869

0.1992 
Soil fertility, ratoon sugarcane yield...

For sugar concentration, purity, fiber and reducing sugars (Table 4), there were no effects from application of limestone and gypsum. For gypsum in ratoon cane without burning, Carvalho et al. (2013) also observed a lack of response in sugarcane for such characteristics, indicating that the use of soil amendments does not hurt the quality of raw material for industry.

In contrast, for stalk and sugar yield there was a quadratic increase from lime application, both in the presence and in the absence of gypsum. It may be observed that the greatest increases occurred when the application rate recommended by Spironello et al. (1996) and double that rate was used. These results may be associated with soil acidity amendment (Talbe 1)and nutrient availability in the soil profile (Tables 2 and 3) brought about by the application of higher rates of
ROSSATO, O. B. et al.

limestone. These results suggest the application of higher rates of soil acidity amendments so as to amend soil acidity at greater depths, to make nutrients available and to increase stalk and sugar yields.

Application of gypsum led to an increase in stalk and sugar yield when applied alone and at the lower lime application rate $\left(900 \mathrm{~kg} \mathrm{ha}^{-1}\right)$. At high rates of limestone application, an effect on stalk and sugar yield from gypsum was not observed. These results may be associated with soil acidity correction (Table 1) and the availability of nutrients in the soil profile (Tables 2 and 3) brought about by the application of high rates of limestone, thus reducing the effects of gypsum in the first year of growth after the application of these products on sugarcane.

Table 4. Values of Pol, purity, fiber, reducing sugar, and stalk, sugar, bagasse, and trash yield taken 12 months (at the time of harvest) after dolomitic lime and gypsum surface application in green sugarcane, and ANOVA significance in Pirassununga, São Paulo, Brazil.

\begin{tabular}{|c|c|c|c|c|c|c|c|c|}
\hline \multirow{2}{*}{$\begin{array}{l}\text { Characteristic } \\
\text { Gypsum, kg ha }^{-1}\end{array}$} & \multicolumn{2}{|c|}{ Pol } & \multicolumn{2}{|c|}{ Purity } & \multicolumn{2}{|c|}{ Fiber } & \multicolumn{2}{|c|}{ Reducing sugar } \\
\hline & $0^{(\mathrm{a})}$ & 1,700 & 0 & 1,700 & 0 & 1,700 & 0 & 1,700 \\
\hline Lime, $\mathrm{kg} \mathrm{ha}^{-1}$ & & --o- & 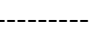 & --- & - & & - & \\
\hline 0 & 18.2 & 18.3 & 91.8 & 92.1 & 12.8 & 12.5 & 0.40 & 0.40 \\
\hline 900 & 18.0 & 17.8 & 92.3 & 91.5 & 12.9 & 12.4 & 0.40 & 0.41 \\
\hline 1,800 & 17.9 & 17.7 & 92.1 & 91.7 & 12.7 & 12.5 & 0.40 & 0.44 \\
\hline 3,600 & 18.5 & 17.6 & 92.0 & 91.2 & 12.6 & 12.4 & 0.39 & 0.43 \\
\hline Mean & $18.2 \mathrm{a}^{(\mathrm{b})}$ & $17.8 \mathrm{a}$ & $92.0 \mathrm{a}$ & $91.6 \mathrm{a}$ & $12.7 \mathrm{a}$ & $12.4 \mathrm{a}$ & $0.40 \mathrm{a}$ & $0.42 \mathrm{a}$ \\
\hline
\end{tabular}

\section{ANOVA}

Lime (L)

\begin{tabular}{|c|c|c|c|c|c|c|c|c|}
\hline \multirow{3}{*}{$\begin{array}{l}\text { Lime, } \mathrm{kg} \mathrm{ha}^{-1} \\
0\end{array}$} & \multicolumn{2}{|c|}{ Stalk yield } & \multicolumn{2}{|c|}{ Sugar yield } & \multicolumn{2}{|c|}{ Bagasse Biomass $^{(\mathrm{d})}$} & \multicolumn{2}{|c|}{ Trash Biomass $^{(\mathrm{e})}$} \\
\hline & & & \multicolumn{6}{|c|}{ - } \\
\hline & $62.0 \mathrm{~b}$ & $71.4 \mathrm{a}$ & $11.3 b$ & $13.1 \mathrm{a}$ & $15.87 \mathrm{~b}$ & $17.85 b$ & $4.34 \mathrm{~b}$ & $5.00 \mathrm{a}$ \\
\hline 900 & $72.3 b$ & $79.9 \mathrm{a}$ & $13.0 \mathrm{~b}$ & $14.2 \mathrm{a}$ & $18.65 b$ & $19.82 b$ & $5.06 \mathrm{~b}$ & $5.59 \mathrm{a}$ \\
\hline 1,800 & $80.5 \mathrm{a}$ & $80.6 \mathrm{a}$ & $14.4 \mathrm{a}$ & $14.3 \mathrm{a}$ & $20.45 \mathrm{a}$ & $20.15 \mathrm{a}$ & $5.64 \mathrm{a}$ & $5.64 \mathrm{a}$ \\
\hline 3,600 & $80.7 \mathrm{a}$ & $82.0 \mathrm{a}$ & $14.9 \mathrm{a}$ & $14.4 \mathrm{a}$ & $20.34 \mathrm{a}$ & $20.34 \mathrm{a}$ & $5.65 \mathrm{a}$ & $5.74 \mathrm{a}$ \\
\hline \multicolumn{9}{|l|}{ Mean } \\
\hline Effect & $\mathrm{Q}^{(\mathrm{c}) *}$ & $\mathrm{Q}^{* *}$ & $\mathrm{Q}^{* *}$ & $\mathrm{Q}^{*}$ & $\mathrm{Q}^{*}$ & $\mathrm{Q}^{* *}$ & $\mathrm{Q}^{*}$ & $\mathrm{Q}^{* *}$ \\
\hline \multicolumn{9}{|l|}{ ANOVA } \\
\hline Lime (L) & \multicolumn{2}{|c|}{$<0.0001$} & \multicolumn{2}{|c|}{$<0.0001$} & \multicolumn{2}{|c|}{$<0.0001$} & \multicolumn{2}{|c|}{$<0.0001$} \\
\hline Gypsum (P) & \multicolumn{2}{|c|}{0.0401} & \multicolumn{2}{|c|}{0.0399} & \multicolumn{2}{|c|}{0.0322} & \multicolumn{2}{|c|}{0.0375} \\
\hline $\mathrm{L} * \mathrm{P}$ & \multicolumn{2}{|c|}{0.0327} & \multicolumn{2}{|c|}{0.0426} & \multicolumn{2}{|c|}{0.0247} & \multicolumn{2}{|c|}{0.0305} \\
\hline
\end{tabular}

* Significant at the 0.05 probability level, ** significant at the 0.01 probability level, and ${ }^{\mathrm{ns}}$ represents no effect. ${ }^{\text {(a) }}$ Gypsum treatments $\left(0\right.$ and $\left.1,700 \mathrm{~kg} \mathrm{ha}^{-1}\right){ }^{\text {(b) }}$ Values followed by the same letter in the rows, within each variable, are not significantly different at $P \leq 0.05$

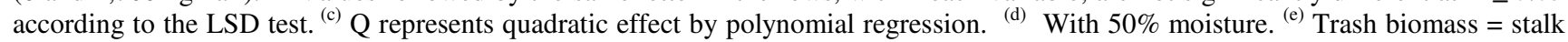
yield x $0.14 \times 0.50$ (considering that $1 \mathrm{Mg}$ of stalk produces $140 \mathrm{~kg}$ of trash and that $50 \%$ of post-harvest residues were collected from the soil surface). 
Furthermore, it also noted that there was small increases in stalk and sugar yield at higher rates of limestone application, associated with gypsum application or not, compared to lower rates of limestone ( $\left.900 \mathrm{~kg} \mathrm{ha}^{-1}\right)$ associated with gypsum. For that reason, at lower rates of limestone, gypsum enhanced the effect of limestone in improving chemical soil conditions (Tables 2 and 3 ), leading to an increase in yield (Table 4). The results of bagasse and trash production followed the same trend observed for stalk yield, indicating that higher rates of lime, in addition to promoting an increase in stalk and sugar yield, increased the amount of bagasse and trash produced. Consequently, more energy and second generation bioethanol can be generated from these sources.

\section{CONCLUSIONS}

The application of gypsum contributes so that the effects of surface application of limestone in soil acidity are able to reach the subsoil layers. However, care should be taken in application of gypsum because it leads to leaching of $\mathrm{Mg}$ and $\mathrm{K}$ from the topsoil layers.

The higher lime surface application rates used in this experiment show acidity amendment and a consequent increase in fertility in the soil profile and stalk, sugar, bagasse, and trash yield in sugarcane.

\section{ACKNOWLEDGMENTS}

The authors would like to thank the Office for Improvement of Personnel in Higher Education (CAPES) for financial support (PROAP) and the National Council for Scientific and Technological Development $(\mathrm{CNPq})$ for a grant for excellence in research to the third author.

RESUMO: O objetivo do presente estudo foi avaliar a correção da fertilidade do solo e produtividade de colmos, açúcar, bagaço e palhiço a partir da aplicação superficial de calcário dolomítico e gesso em cana soca. O arranjo fatorial foi composto por 4 doses de calcário dolomítico $\left(0,900,1800\right.$ e $\left.3600 \mathrm{~kg} \mathrm{ha}^{-1}\right)$ e duas doses de gesso $(0$ e $1700 \mathrm{~kg}$ $\mathrm{ha}^{-1}$ ). O experimento foi realizado no período de outubro de 2006 a outubro de 2007, iniciando-se na estação chuvosa após a colheita da segunda soqueira. A variedade utilizada foi a SP813250 em plantio comercial de cana crua da Usina de São Luiz (47²5'33 "W; 2159'46", 627 M de altitude), localizado em Pirassununga, estado de São Paulo, no sudeste do Brasil. Após 12 meses, o experimento foi colhido, determinado os parâmetros tecnológicos e amostras de solo foram coletadas e analisadas. O gesso atua como um condicionador subsuperficial contribuindo assim, para que os benefícios da aplicação superficial de calcário na correção da acidez do solo, alcancem camadas mais profundas e, portanto, permitindo o desenvolvimento do sistema radicular das plantas em maior profundidade. No entanto, a aplicação de gesso pode proporcionar lixiviação de $\mathrm{Mg}$ e $\mathrm{K}$ das camadas superficiais. As maiores doses de calcário aplicadas superficialmente propiciaram correção da acidez do solo e consequente incremento na fertilidade do solo, produtividade de colmos, açúcar, bagaço e palhiço da cana.

PALAVRAS CHAVES: Sacharum spp. Atributos químicos do solo. Colmos. Açúcar. Bagaço e palhiço.

\section{REFERENCES}

ALCARDE, J. C.; RODELLA, A. A. Qualidade e legislação de fertilizantes e corretivos. In: CURI, N.; MARQUES, J. J.; GUILHERME, L. R. G.; LIMA, J. M.; LOPES, A. S.; ALVAREZ, V. H. (Ed.). Tópicos em Ciência do Solo. Viçosa, Brazil: Sociedade Brasileira de Ciência do Solo, 2003. p. 291-334.

ALLEONI, L. R. F.; CAMBRI, M. A.; CAIRES, E. F. Atributos químicos de um Latossolo de cerrado sob plantio direto, de acordo com doses e formas de aplicação de calcário. Revista Brasileira de Ciência do Solo, Viçosa, v. 2, p. 923-934, 2005.

ALVAREZ, V. H.; ROSCOE R.; KURIHARA, C. H.; PEREIRA, N. F. Enxofre. In: NOVAIS, R. F.; ALVAREZ, V. H.; BARROS, N. F.; FONTES, R. L., CANTARUTTI, R. B.; NEVES, J. C. L. (Ed.). Fertilidade do solo, Viçosa, MG: Sociedade Brasileira de Ciência do Solo. 2007, p. 595-644. 
AMARAL, A. S.; ANGHINONI, I.; HINRICHS, R.; BERTOL, I. Movimentação de partículas de calcário no perfil de um Cambissolo em plantio direto. Revista Brasileira de Ciência do Solo, Viçosa, v. 28, p. 359-367, 2004.

BEN - BALANÇO ENERGÉTICO NACIONAL - 2014. Available at:

$<$ https://ben.epe.gov.br/BENRelatorioSintese2014.aspx>. Accessed on 11 August 2014.

CAIRES, E. F.; ALLEONI, L. R. F.; CAMBRI, M. A.; BARTH, G. Surface application of lime for crop grain production under a no-till system. Agronomy Journal, v. 97, p. 791-798, 2005.

https://doi.org/10.2134/agronj2004.0207

CAIRES, E. F.; KUSMAN, M. T.; BARTH, G.; GARBUIO, F. J.; PADILHA, J. M. Alterações químicas do solo e resposta do milho à calagem e aplicação de gesso. Revista Brasileira de Ciência do Solo, Viçosa, v. 28, p. 125-136. 2004.

CAIRES, E. F.; JORIS, H. A. W.; CHURKA, S. Long-term effects of lime and gypsum additions on no-till corn and soybean yield and soil chemical properties in southern Brazil. Soil Use and Management, v. 27, n. 1, p. 45-53. 2011. https://doi.org/10.1111/j.1475-2743.2010.00310.x

CAIRES, E. F.; CORRÊA, J. C. L., CHURKA, S.; BARTH, G., GARBUIO, F. J. Surface application of lime ameliorates subsoil acidity and improves root growth and yield of wheat in an acid soil under no-till system. Scientia Agricola, Piracicaba, v. 63, p. 502-509, 2006. https://doi.org/10.1590/S0103-90162006000500013

CARVALHO, J. M.; ANDREOTTI, M.; BUZETTI, S.; PASSOS, M. Produtividade de cana soca sem queima em função do uso de gesso e vinhaça. Pesquisa Agropecuária Tropical, Goiânia, v. 43, p. 1-9. 2013.

CAMARGO, M. S.; BARBOSA, D. S.; RESENDE, R. H.; KORNDÖRFER, G. H.; PEREIRA, H. S. Fósforo em solos de Cerrado submetidos à calagem. Bioscience Journal, v. 26, p. 187-194, 2010.

https://doi.org/10.1590/S1983-40632013000100001

CASAGRANDE, J. C.; ALLEONI, L. R. F.; CAMARGO, O. A.; BORGES, M. Adsorção de fosfato e sulfato em solos com cargas variáveis. Revista Brasileira de Ciência do Solo, Viçosa, v. 27, p. 51-59. 2003.

FERNANDES, A. C. Cálculos na agroindústria de cana-de-açúcar. 3.ed. Piracicaba: STAB, 416 p. 2011.

HASSUANI, S. J.; LEAL, M. R. L. V.; MACEDO, I. C. Biomass Power Generation: Sugar Cane Bagasse and Trash. CTC/PNUD, Piracicaba, SP, Brazil. (Série Caminhos para sustentabilidade). 2005.

MORELLI, J. L.; DALBEN, L. C.; ALMEIDA, J. O. C.; DEMATTÊ, J. A. M. Calcário e gesso na produtividade da cana-de-açúcar e nas características químicas de um Latossolo de textura média álico. Revista Brasileira de Ciência do Solo, Campinas, v. 16, p. 187-194. 1992.

RAIJ, B. van. Gesso na agricultura. Instituto Agronômico, Campinas. 233p. 2008.

RAIJ, B. van. Fertilidade do solo e manejo de nutrientes. IPNI, 420p. 2011.

RAIJ, B. van; CANTARELLA, H.; QUAGGIO, J. A.; FURLANI, Â. M. C. Recomendações de adubação e calagem para o Estado de São Paulo. 2.ed. Campinas, Instituto Agronômico,. 285p. (Boletim Técnico, 100). 1996.

RAIJ, B. van.; ANDRADE, J. C.; CANTARELLA, H.; QUAGGIO, J. A. Análise química para avaliação da fertilidade de solos tropicais. Campinas, Instituto Agronômico, 284p. 2001. 
ROSSATO, O. B.; CERETTA, C. A.; DA SILVA, L. S., BRUNETTO, G.; ADORNA, J. C.; GIROTTO, E.; LORENZI, C. R. Correction of soil acidity in the subsurface of an oxisol with sandy loam texture under notillage. Revista Brasileira de Ciência do Solo, Viçosa, v. 33, p. 659-667. 2009.

SILVA, R. C.; CHIEN S. H.; PROCHNOW, L. I. Available phosphorus evaluated by three soil tests in a Brazilian tropical Oxisol treated with gypsum. Soil Science, v. 175, n. 5, p. 233-239. 2010. https://doi.org/10.1097/SS.0b013e3181e04a45

SORATTO, R. P.; CRUSCIOL, C. A. C. Atributos químicos do solo decorrentes da aplicação em superfície de calcário e gesso em sistema plantio direto recém-implantado. Revista Brasileira de Ciência do Solo, Viçosa, v. 32, p. 675-688. 2008a.

SORATTO, R. P.; CRUSCIOL, C. A. C. Dolomite and phosphogypsum surface application effects on annual crops nutrition and yield. Agronomy Journal, v. 100, p. 261-270. 2008 b.

https://doi.org/10.2134/agrojnl2007.0120

SPIRONELLO, A.; RAIJ, B. van; PENATTI, C. P.; CANTARELLA, H.; MORELLI, J. L.; ORLANDO FILHO, J.; LANDELL, M. G. A.; ROSSETTO, R. Cana-de-açúcar. In: RAIJ, B. van; CANTARELLA, H.; QUAGGIO, J. A.; FURLANI, Â. M. C. (Ed.). Recomendações de adubação e calagem para o Estado de São Paulo. Campinas: IAC, (Boletim Técnico n. 100). 1996. 237-239.

UDOP - União dos Produtores de Bioenergia. Com preço em alta, aumenta ritmo de geração nas usinas de biomassa. Available at: $<$ http://www.udop.com.br/index/cana/download/indicadores/index.php?item=noticias\&cod=1112408>. Accessed on: 09 August 2014.

VITTI, G. C. Enxofre no solo. In: Simpósio sobre interpretação de análise química de solo e planta para fins de adubação, 1., Botucatu. Anais.... Botucatu, FCA-UNESP/FEPAF/ANDA/ POTAFOS, 39p. 1988.

TRIVELIN, P. C. O.; CANTARELLA, H.; FRANCO, H. C. J.; FARONI, C. E.; OTTO, R.; TRIVELIN, M. O.; TOVAJAR, J. G. Mineralização da palhada e crescimento de raízes de cana-de-açúcar relacionados com a adubação nitrogenada de plantio. Revista Brasileira de Ciência do Solo, Viçosa, v. 32, p. 2757-2762. 2008.

ZAMBROSI, F. C. B.; ALLEONI, L. R. F.; CAIRES, E. F. Aplicação de gesso agrícola e especiação iônica da solução de Latossolo sob sistema plantio direto. Ciência Rural, Santa Maria, v. 37, p. 110-117, 2007. https://doi.org/10.1590/S0103-84782007000100018 